\title{
Building, celebrating, participating: A Macdougall mini-dynasty in Australia, with some thoughts on multigenerational biography
}

\section{PAT BUCKRIDGE}

This article poses a question that arose out of the process of researching and writing an Australian Dictionary of Biography $(A D B)$ entry on the veteran Sydney columnist Jim Macdougall. Seeking, in the usual way, merely to identify my subject's immediate ancestry, I noticed something slightly unusual about it, which was that Macdougall's father and grandfather were as prominent in public life as he, in different but related fields. (His son, too, was sufficiently prominent to have been awarded a Medal of the Order of Australia for services to regional medicine, in 2006. ${ }^{1}$ As it happens, neither of the older Macdougalls appears in the $A D B$, though a case could certainly have been made for both of them, as will become evident. But the question I want to address is not whether they should have been included in the $A D B$, but whether the lives of these three can usefully be considered as a grouped biographical entity signifying something more than the sum of its parts, which is to say more than the three separate lives.

Meaning is routinely adduced from three or more generationally successive lives in various historiographic contexts. In royal dynastic histories of the older type, for example, it would not be unusual to find an individual monarch's attributes and policies being interpreted as, in part, a continuation, modification or rejection of those of his or her ancestors. Histories of aristocratic families-especially those with self-conscious traditions of prominent public service, such as the Churchills and the Russells in Britain-sometimes adopt a similar perspective, in which the march of generations, usually through the male line, can be used not just as a form of familial aggrandisement, but also as a lens through which to observe and interpret the unfolding of a series of real historical possibilities.

In white-settler colonies such as Australia, upper-class genealogical histories can be tinged with pathos and irony, preoccupied as such narratives sometimes are with the loss of wealth and status and even-following one popular Victorian trope-with the spectre of moral and physical degeneration on the edge of empire. Where the

1 Australian Honours Search Facility website (Canberra: Department of the Prime Minister and Cabinet, 2006), honours.pmc.gov.au/honours/awards/1133250. 
generational trajectory is ascending (or flat), it is often because the family narrative is interwoven with the colonial and postcolonial progress of a particular professionbe it politics, medicine or the law-and can thus be used to explore longitudinal institutional processes such as the reproduction and elaboration of ethical norms and professional expertise, and the development and extension of multigenerational professional networks. Karen Fox's $A D B$ essay on the legal 'dynasties' of the Stephens and Street families shines a light on two Australian narratives of this type. ${ }^{2}$

Modern family biographies generally seek to discover substantive, not merely nominal, continuities and transmissions between the generations. Sometimes-as in the case of the six generations of Thomas Archers who owned and inhabited Woolmers Estate in Tasmania for 170 years - the cultural process by which a 'lineage' can be constructed, retrospectively, out of the mere succession of generations may be the most interesting thing about the dynasty as a whole. ${ }^{3}$ In other cases, the dynasty may be given historical substance by virtue of its continuing connection with grander narratives. Thus, for example, Stephen Foster's biography of six generations of the Scottish Macpherson family, from the mid eighteenth to the late twentieth century, presents them as a concrete familial instantiation of the whole British imperial project, extending over many parts of the globe-North America, the Caribbean, India and New South Wales_-and involving many different activities, enterprises, professions and occupations. ${ }^{4}$

Even shorter series of generations, however, can sometimes claim a significance wider than the single individuals who constitute the series-perhaps more easily than the longer series, since across, say, three generations there is at least the possibility of direct personal interactions. Andrew Motion's The Lamberts: George, Constant and Kit is one useful and interesting example, in which the three generations-painter, classical composer and musical impresario_relate to one another in complex and mutually revealing ways. ${ }^{5}$

Three generations might be regarded as the minimum length of such a series, in the same way that Edward Shils defined a tradition as a pattern of behaviour or belief that persists through at least three generations. ${ }^{6}$ Shils made that stipulation on the grounds that at least two distinct acts are needed to establish the relative independence of the pattern's existence from its originating agent-namely, an act of receiving a transmitted pattern from a preceding generation and a second act of passing it on to, and having it received by, a succeeding generation. The usefulness

\footnotetext{
2 Karen Fox, 'Australian Legal Dynasties: The Stephens and the Streets', Australian Dictionary of Biography (Canberra: National Centre of Biography, The Australian National University, 2015), adb.anu.edu.au/essay/10/ text36680.

3 Patrick Buckridge, 'Generations of Books: A Tasmanian Family Library, 1816-1994', Library Quarterly 76, No. 4 (2006): 388-402, doi.org/10.1086/511199.

4 Stephen Foster, A Private Empire (Sydney: Murdoch Books, 2011). Andrew Motion, The Lamberts: George, Constant and Kit (London: Faber \& Faber, 2012).

6 Edward Shils, Tradition (London: Faber \& Faber, 1981), 15.
} 
of the Shils model of tradition for a three-generational biography, however, might be qualified by the need for a stronger recognition of difference, dialogue and complementarity between the generations; Shils's focus on similarities, repetitions and continuities, in other words, could be seen as an oversimplification of the intergenerational relations in a biographical series.

These issues will be taken up again in the conclusion to this paper, when the Macdougalls' careers have been examined and compared. Accordingly, the next three sections will comprise selective narratives of the working lives of the three mengrandfather, father and son-with some observations of how those lives intersected to form what might have to be termed a 'mini-dynasty'.

\section{Dugald Graeme Macdougall (1833-1879)}

Dugald Macdougall migrated to Victoria in 1852, aged 19, from Greenock, Scotland. The son of a wine and spirit merchant in that town, he had worked in the Harbour Trust Office after leaving school and, on arriving in Australia, first went into produce trading between Melbourne and Launceston. He soon acquired a parcel of land in the Kyneton farming district north of Melbourne from which, for a few years, he supplied farm produce to the growing mining centres of Maryborough and Bendigo (called Sandhurst between 1854 and 1891). In 1855, he seized an opportunity to establish his own produce dealership on the Bendigo goldfields, transporting produce himself by bullock dray from Kyneton to the grocery store on Golden Square, and later moving to Market Square. The business flourished and grew, but in 1859, Macdougall sold up and plunged on to a large claim at Specimen Hill, Long Gully, where he and a partner discovered a promising quartz lode. Understanding what was needed to realise its potential, he raised $£ 10,000$ and erected a combined winding, quartz-crushing and pumping plant, extending many stalled claims well below the water table, and was later credited with advancing the industry significantly. The venture failed in the end, but Macdougall stayed on as manager and initiated several more mining-related hydraulic engineering projects in following years, including the completion of the Bendigo Sludge Channel ${ }^{7}$ and, notably, the still-functioning Crusoe Reservoir. ${ }^{8}$ This last project was undertaken by the Yorkshire Mining Company-of which Macdougall was chairman of directors - chiefly to provide water for their own nearby crushing works, and only after considerable resistance from rival interests. ${ }^{9}$ It was completed - with more than a million bricks used in its construction-in the early 1870 s. ${ }^{10}$

\footnotetext{
Anon., 'Death of Mr. D. Macdougall', Bendigo Advertiser, Saturday, 16 August 1879, 2.

Anon., 'Testimonial to Mr. Macdougall', Bendigo Advertiser, Wednesday, 11 October 1876, 2.

D. Macdougall, 'The Yorkshire Mining Company', [Letter to the editor], Bendigo Advertiser, Monday, 7 May 1866,3 .

10 'Crusoe Reservoir \& No. 7 Park' (Bendigo Region website), www.bendigoregion.com.au/explore-bendigo/ crusoe-reservoir.
} 
In 1861, Macdougall married, with Presbyterian forms, Mary Anne Mills Brocklebank, the 18-year-old daughter of a prominent local identity, the auctioneer Thomas Brocklebank, a Londoner. The couple had two daughters, Marion (b. 1862) and Kate (b. 1865), and on 17 November 1872, a son, who was given the same names as his father. ${ }^{11}$ Throughout the rest of his short and active life, Dugald Macdougall (the elder) continued to engage in speculative mining enterprises, with unflagging energy but mixed financial success, his most signal misfortune being the sale of a half-share in a claim a few days before gold was discovered there in large amounts.

Returning to Bendigo from a short stay in Heathcote as manager of an antimony mine, he went into business as an insurance agent and official liquidator. His involvement in the broader community was also growing. Beginning, unsurprisingly enough, with membership of the Bendigo Caledonian Society in $1859,{ }^{12}$ Dugald senior the following year chaired the Bendigo Hospital's Board of Management, remaining on the board for many years. He also chaired various community entertainments, such as the White Hills Popular Readings in 1868 (his Presbyterian background perhaps showing in his congratulations to the organising committee 'on having avoided anything low or vulgar in their readings'). He is also listed as a member of the founding committee of the new Art Union of Victoria in 1871, which was established 'for the promotion of fine arts in Victoria'. ${ }^{13}$ By this time, he had been involved in local politics for some time, and had been elected councillor for the municipal ward of Sutton, which he represented for 10 years. From 1871 to 1873 , he filled the position of mayor of Bendigo for three consecutive one-year terms, laying the memorial stone for the magnificent new bells and 30-metre belltower of St Paul's Anglican Church (later cathedral), and celebrating, as he did, the rapid material progress of the district, but also the city's attention to its 'higher duties to humanity', which was evident in the establishment of charitable institutions for the aged, infirm and homeless, several public schools and a church with a peal of eight bells cast by Meyer and Steinbank of London. ${ }^{14}$

The bells' memorial stone reads:

How elated, how joyful, would be the feelings of hundreds and thousands of the inhabitants of this district, and of the citizens of Sandhurst, when they heard this peal of bells for the first time. The sweet music would bring back to their recollections the happy days many years ago, and recall scenes in distant lands, where they heard the same merry, happy sounds cheering and stimulating them and ministering to their best feelings. ${ }^{15}$

11 Family information from the Victorian Registry of Births, Deaths and Marriages, and 'Family Notices' in the Bendigo Advertiser for 1871 .

12 'The Bendigo Caledonian Society', Bendigo Advertiser, Tuesday, 15 February 1859, 2.

13 'Art Union of Victoria', The Argus, [Melbourne], Friday, 3 March 1871, 6.

14 For the history of the bells, which are still in place but are no longer rung, see St Paul's Cathedral website, www.stpaulsbendigo.org.au/cathedral.

15 Anon., 'Memorial Stone of the Bendigo Bells', Bendigo Advertiser, Thursday, 24 October 1872, 2. 
Throughout this period, Macdougall was an active member of the Liberal Association of Victoria, seconding a successful motion after the defeat of the radical liberal George Higinbotham in 1871 expressing the meeting's 'surprise and indignation at the rejection of the hon. George Higinbotham by the constituency of Brighton' and recording 'its unabated confidence in and gratitude to him for the great services he has rendered to the people of Victoria in Parliament'. ${ }^{16}$ Two weeks later, at their anniversary meeting, Macdougall proposed the health of the new ministry in Melbourne and its premier, James McCulloch, expressing gratitude to him for establishing a strong government, free from scandal and corruption, and effecting 'important social reforms'; these included publicans' licensing reforms, the attempt (led by the unfortunate Higinbotham, but unsuccessful at this time) to introduce a system of universal secular education, a 'wise and equitable' new code of mining regulations and the long-delayed reforms to the graft-ridden matter of civic water supply, which the government had just announced its intention to localise (an opportunity Macdougall translated into the Crusoe Reservoir, which was opened during his mayoralty, in August 1872). Towards the end of his term, Macdougall also envisioned the transformation of 'a dusty old mining site' in North Bendigo into a botanical garden and public recreation area-Bendigo's first- to be laid out around an artificial lake in imitation of Ballarat's Lake Wendouree. Having reserved the area for this purpose, Macdougall insisted, against some local opposition, on commissioning William Guilfoyle, the director of the Melbourne Botanic Gardens, to design what came to be called Lake Weeroona. It opened officially in 1878 and has been maintained continuously as a popular public park and recreation reserve ever since. ${ }^{17}$

Macdougall was also, for most of his time on the council, chief magistrate of the city and, in 1876, he resigned from the council to apply for the position of town clerk, at a salary—controversially high—of $£ 450$ per annum. He performed his duties with great 'ability and integrity' until his death from a sudden, though not unforeseen, heart attack on 15 August 1879. He was not without enemies, however, because, as some believed:

[A]s a public man he has not escaped the wrath of some towards whom, perhaps, in his judicial capacity, he has had to administer a bolus, which they found very nauseous in swallowing. ${ }^{18}$

16 Anon., 'Bendigo Liberal Association', Bendigo Advertiser, Friday, 17 March 1871, 2.

17 'Lake Weeroona' (City of Greater Bendigo, 2019), website, www.bendigo.vic.gov.au/Things-to-Do/Parks-andGardens/Lake-Weeroona. See also Graeme Butler, Eaglehawk \& Bendigo Heritage Study 1993. Volume 3 (Issuu Inc., 26 July 2017), 97, issuu.com/graemebutler21/docs/eaglehawk_bendigo_hs_1993-_vol_3.

18 Anon., 'The Town Clerkship', Bendigo Advertiser, Saturday, 22 April 1876, 2. 
What this referred to specifically is not clear, but there were other, more public conflicts. For example, in the midst of the town's domestic and industrial water supply crisis, the Bendigo Advertiser had editorialised against 'Councillor Macdougall's pet Crusoe scheme', adding — with more animus than elegance: 'If ever there was a reservoir badly situated as respects the results of the giving way of a dam, it is this same Robinson Crusoe folly. ${ }^{19}$ He probably also made an enemy for life of the city valuer, G.W. Knight, by exposing potential corruption in his out-of-court settlements or 'squaring' of several appeals against council property assessments. ${ }^{20}$ Macdougall's Presbyterian rigour in that connection seems even to have antagonised then mayor Robert Clark, a man of more relaxed standards, who opined in advance of Macdougall's successful motion to call Knight to account that in fact too much had been made of the affair'. ${ }^{21}$

Such clashes were freely acknowledged by Macdougall himself later in the same year (1876) at a testimonial in his honour on the occasion of his retirement as councillor and Justice of the Peace to take on the role of town clerk. He had 'trod on some people's toes'; he had 'an impetuous temperament, [which] may have carried him away at times'; but he believed he had 'done his best for the benefit of his fellow citizens' and was gratified 'that his labors in the public behalf as a representative man had been so well recognised'. ${ }^{22}$

What emerges from this frank if not unnecessarily modest self-appraisal, combined with the observations of others on his conduct in public life, is a picture of a somewhat driven man of great energy and ambition, with a streak of moral rigour and an enthusiasm for 'public service' in the broadest sense: practically, in initiating and completing several major infrastructure projects for the benefit of Bendigo's citizens; politically, in winning elected positions that allowed him to directly influence and direct the city's economic and cultural development; judicially, in overseeing a scrupulously honest and impartial justice system; and administratively, in taking on the job of town clerk, which his experiences on the council had shown to be a key position in a rapidly growing town such as Bendigo for ensuring diversified and therefore sustainable prosperity. Perhaps only in a place such as Bendigo in the 1860s would it have been possible for Macdougall to express his talents in so many different capacities and directions while also maintaining a strong vision of the whole community and its aspirations.

19 Anon., 'Water Supply', Bendigo Advertiser, Saturday, 25 March 1876, 2.

20 Anon., 'Appeals Against Assessments', Bendigo Advertiser, Monday, 3 April 1876, 2.

21 Anon., 'Ordinary Meeting', Bendigo Advertiser, Saturday, 8 April 1876, 4.

22 Anon., 'Testimonial to Mr. Macdougall'. 


\section{Dugald Graeme Macdougall (1872-1947)}

D.G. Macdougall, as he seems to have been called in public life, was born in Bendigo (Sandhurst) in 1872, the only son and eldest child of Dugald and Mary Anne. In 1882, three years after the death of his father, he and his mother seem to have left Bendigo to live with his mother's brother in Dalby, on the Darling Downs in Queensland, where he probably attended the local primary school for two years before moving to Brisbane, perhaps boarding with a family while attending secondary school. After tenth grade, he returned to Dalby to work as a reporter with the Dalby Herald and, by the end of the following year, aged just 16, he became both editor and part-owner of the small weekly paper-an achievement that seems to have resonated through his later life as proof of his energy and precocity, since it features in several later public summations of his career, including obituaries. Five years later, in January 1893, he married a Dalby girl, Mary Ryan, the daughter of the town butcher, ${ }^{23}$ and four months later their first child, a son, Carlyle, arrived ${ }^{24}$ Some 18 months later, ${ }^{25}$ the family moved 500 kilometres west to Charleville, where Dugald took on the editorship and management of the weekly Charleville Times and played local cricket, and their second son, D'Arcy Graeme, was born. ${ }^{26}$ Subsequently, the family moved north to Charters Towers, where Dugald briefly edited the daily Mining Standard before finally moving to Brisbane, in 1898. Here he worked as a subeditor on the Evening Observer and, in 1903, when C.H. Buzacott founded the Brisbane Daily Mail, he became one of its original literary staff. ${ }^{27}$ In that same year, the Macdougalls' third son, James, was born. ${ }^{28}$

The Macdougalls may have had second thoughts about the wisdom of moving their young family to Brisbane when, in April 1900, the first cases of bubonic plague were reported in the suburbs of Woolloongabba and Kangaroo Point. ${ }^{29}$ The outbreak lasted for two years, with 56 notified cases and 25 deaths. Macdougall was secretary of the Brisbane Vigilance Committee set up by the city council to organise inspections, drainage, rodent extermination, demolitions and quarantine and to regulate publicity. This was the first of many ventures in strategic organisationwhat might now be called 'event management' — which would soon draw him away from journalism proper. It was also, perhaps, his first serious engagement with the challenges of public health administration, to which, even more than his father before him, he devoted much attention for the rest of his career.

23 Certificate of Marriage, Queensland Register of Births, Deaths, Marriages and Divorces.

24 Certificate of Birth, Queensland Register of Births, Deaths, Marriages and Divorces.

25 'Country Letters', Brisbane Courier, Thursday, 23 August 1894, 6.

26 'Sporting Column', Charleville Times, Saturday, 29 August 1896, 1.

27 'A Man of Mark: Mr D.G. MacDougall: A Master Organiser', Prahran Telegraph, [Melbourne], Saturday,

10 December 1921, 5.

28 Certificate of Birth, Queensland Register of Births, Deaths, Marriages and Divorces.

29 'Black Death in Queensland', [Blog] (Brisbane: State Library of Queensland, 12 September 2008), www.slq. qld.gov.au/blogs/jol/black-death-queensland. 
The family moved to South Yarra in Melbourne in about 1907, where Dugald worked as editor of the Prahran Telegraph for two years, during which time, according to his successor, 'his sterling abilities were recognised, and the magnetic influence he possesses for making staunch friends had full scope, and he became very popular'. ${ }^{30}$ His next move was to the original Melbourne Punch, a weekly, where for nine years he was chief contributor and leader writer, ${ }^{31}$ a job that allowed him to indulge a talent for writing humorous and sentimental short stories and satirical pieces, but also to pursue his interest in local civic and community issues-regional firefighting services and water supply, for instance, and community education and entertainment-as well as broader national policy issues such as trade protection and foreign imports. ${ }^{32}$

Soon after the outbreak of war in 1914, Macdougall was commissioned by the Young Men's Christian Association (YMCA) to direct fundraising in support of the association's considerable contributions of personnel and equipment to the Australian army and navy at home and abroad. The fundraising was conducted chiefly through nationwide press publicity. For nearly three years, Macdougall maintained a news service to more than 650 Australian newspapers on behalf of the YMCA, and in that time succeeded in raising some $£ 320,000$ for the organisation's army and navy work. ${ }^{33}$ In February 1918, he was appointed organising secretary of YMCA Australasia, with responsibility for further fundraising and publicity. ${ }^{34}$ A less than pleasing obligation that arose a year after this appointment was to defend the YMCA against attacks on its allegedly 'sectarian character' made in the Catholic Advocate, seemingly provoked by the new 'Red Triangle' appeal he had recently initiated. Macdougall deplored the cynicism, malice and ignorance of such accusations, and had a long letter from a Catholic returned soldier reprinted in The Age attesting to the 'Y's' even-handed and generous provision of worship venues in the field for all denominations; and indeed there seems no evidence the YMCA ever proselytised in favour of anything narrower than the nondenominational 'muscular Christianity' of its founders. ${ }^{35}$

The experience may have soured Macdougall's hitherto sanguine view of people's generosity and cooperativeness, because two years later he left the YMCA behind and moved to a new job as secretary of Melbourne's 50-year-old Alfred Hospital, a position that involved publicity and fundraising, but also increasing responsibility for financial administration. He brought with him some new ideas about raising funds for public institutions - notably, that of a 'women's auxiliary'. Immediately

30 'A Man of Mark', 5.

31 'Death of Citizens' Committee Official', Daily Telegraph, [Sydney], Thursday, 17 July 1947, 6.

32 D.G. Macdougall, 'Strenuous Protection', [Short story], Punch, [Melbourne], 2 February 1911, 7; D.G.

MacDougall, 'Some Preventible Risks', [Letter to the editor], The Age, [Melbourne], Monday, 22 December 1913, 10.

33 'A Man of Mark', 5.

34 'Another Appeal Launched', Telegraph, [Brisbane], Tuesday, 26 February 1918, 3.

35 Letter to the Editor, The Age, [Melbourne], Thursday, 19 December 1918, 4. 
after raising $£ 51,000$ for building extensions, in a one-off appeal, at a cost of only 1.75 per cent of the amount raised (a record for a public financial appeal in Australia), ${ }^{36}$ Macdougall outlined his strategy for securing long-term maintenance funding for the Alfred in a letter to The Argus. The activity of the auxiliary, he argued,

does not involve any call on the public for money, but is designed to save expenditure at the hospital in innumerable ways, accomplished by slight individual, but keenly systematised, service on the part of well-wishers. Thus, supplies of hospital commodities are provided-an equivalent, of course, to money. Well-wishers who plan an entertainment for the hospital are making no appeal to the public, for they give value for money, which is readily sought; yet the result is a monetary gain to the institution. ${ }^{37}$

The idea took off and, within two years, there were 13 affiliated branches of the Alfred auxiliary around the state - a mode of organisation as efficient and admirable, in the view of its acting chairman, Sir Brudenell White, as the British Empire itself - and they had contributed to the hospital $£ 8,500$ in cash and kind over that period. ${ }^{38}$ Two years later, Macdougall was presented with a gold watch and chain as a tribute to his 'ability as secretary of the hospital, and to his work in founding the hospital auxiliary movement in Melbourne'. ${ }^{39}$ In the interim, he had come up with an idea for an inhouse hospital publication, The Alfred, a sizeable magazine mixing updates on new facilities and organisational changes with expert articles on medical issues such as cancer and 'bright and entertaining' sketches, cartoons and poems. Macdougall edited the magazine in addition to his main duties for several years. ${ }^{40}$

Another year, another gold watch. In 1927, Macdougall took his leave of the Alfred after five years' service and was farewelled in the traditional manner. In November, the family — now just Dugald, Mary and daughter, Sheila, the boys having all left home-upped stakes and moved to Sydney so Macdougall could take on a new job as research and publicity officer for the Sydney Chamber of Commerce. ${ }^{41} \mathrm{He}$ left that job after two and a half years ${ }^{42}$ to return to his forte, as organising secretary of the Sydney Hospital, taking responsibility, again, for establishing a women's auxiliary for fundraising. ${ }^{43}$ By the end of 1930 , however, after a mere eight months in the role, the Great Depression took its toll, and his position disappeared. ${ }^{44} \mathrm{~A}$ month later, he wrote an account of the humiliating process of 'going on the dole', which was published in the Sydney Morning Herald in February 1931, opening as follows:

\footnotetext{
36 'A Man of Mark', 5.

37 'Charitable Appeals', The Argus, [Melbourne], Saturday, 5 November 1921, 20.

38 'Alfred Hospital Auxiliary', The Argus, [Melbourne], Tuesday, 23 September 1924, 22.

39 'Personal', The Argus, [Melbourne], Wednesday, 1 September 1926, 24.

40 'The "Alfred” Magazine', The Age, [Melbourne], Wednesday, 9 December 1925, 14.

41 'Personal', Herald, [Melbourne], Tuesday, 8 November 1927, 7.

42 'Personal', Sydney Morning Herald, Thursday, 10 April 1930, 8.

43 Daily Pictorial, [Sydney], Saturday, 9 August 1930, 13.

44 Macdougall is still named as organising secretary in December, and the dismissal must have occurred in January. 'Crowning Ceremony', Sydney Morning Herald, Friday, 12 December 1930, 4.
} 
Before I became a recipient of the dole last week, I confess that I shared in a common misconception, not only of the general operation of the form of charity and the extent of its relief to individual cases, but of the effect that the grant might possibly have on the morale or character of the recipient. I have not changed my attitude to the dole or its principle because I have been driven by circumstances to accept it, but because, in the light of practical and personal experience, I find that I was entirely uninformed on the matter. ${ }^{45}$

What then follows is a 2,500-word description of the long and sometimes humiliating procedures for proving need, registering for and finally obtaining the weekly allowance of 11 shillings and threepence-halfpenny (about \$52 in 2019 coin $)^{46}$ in coupons, concluding glumly:

To stand among that army of well-set-up unemployed, to look up into the blue Empyrean of a cloudless Australian summer sky, to gaze across the rippling waters of our matchless harbour, to visualise the great inviting empty spaces of Australia's fertile hinterlands, and then answer the summons of the dole, makes one wonder whether, though 'God's in His heaven, all is right with the world. ${ }^{\text {'47 }}$

As one who no doubt felt some embarrassment himself, Dugald signed the article with a pen-name, 'Telemachus', which he had first used for humorous anecdotes in Smith's Weekly in 1929, and had begun to use for letters he wrote to the Sydney Morning Herald on subjects close to his heart, such as the inadequate system of government funding for public hospitals. ${ }^{48}$ Perhaps the Homeric pen-name was a private gesture of respect to the father who had made his odyssey from Greenock and died in Bendigo precisely half a century earlier? He had also used the pen-name 'Graeme' frequently for contributions to Smith's Weekly since 1920, its first full year of existence; ${ }^{49}$ these were invariably short pieces: anecdotes with a 'bush' or suburban flavour, occasional bits of verse, but also snippets of news about the comings, goings and doings of well-known Melbourne, and later Sydney, identities - not dissimilar, in fact, to the mix of elements with which his son James would later fill his popular columns. But the 'Telemachus' pieces, by contrast, were mostly long and serious essays published by the Sydney Morning Herald, presenting closely argued discussions of a range of topics, extending over nine years. Issues included the constitutional powers of the state governor and the prerogatives of the Upper House (published in May 1931, a year before NSW governor Sir Philip Game's notorious dismissal of NSW premier Jack Lang), employment and the exchange rate (1932), world disarmament (1932), the Polish 'Corridor' (1933), the English

45 'Telemachus', 'The Dole: A Personal Note', Sydney Morning Herald, Tuesday, 24 February 1931, 8.

46 See 'Pre-Decimal Inflation Calculator' (Sydney: Reserve Bank of Australia, 2001-19), www.rba.gov.au/ calculator/annualPreDecimal.html.

47 'Telemachus', 'The Dole', 8.

48 'Our Public Hospitals', Sydney Morning Herald, Saturday, 27 September 1930, 8.

49 The evidence for these identifications is an article about Macdougall in Smith's Weekly: 'Man Who Told World About Bridge', Smith's Weekly, [Sydney], Saturday, 2 April 1932, 4. 
monarchy (1935, 1937), Sydney's public transport system (1935, 1936), tariff policy, censorship, Italy's attack on Abyssinia, the League of Nations, empire defence (1936) and-embarrassingly_the extreme improbability of a German conquest of France (August 1939). There were also articles on George Bernard Shaw and Russian theatre.

The authorship of these 'Telemachus' articles, however, is something of a puzzle. The evidence for Macdougall's authorship is in an anonymous feature article about him published in Smith's Weekly in 1932, which states: 'Despite other activities, he wields a graceful pen as a contributor, to "Smith's" and other papers, as "Graeme" and "Telemachus" (my emphasis). ${ }^{50}$ Against this must be placed Gavin Souter's unreferenced assertion that the young Warwick Fairfax used 'Telemachus' as his pen-name in the 1930s. ${ }^{51}$ The academic quality of the 30-odd articles published from May 1931 to August 1939 lends support to Souter's assertion, given that Fairfax had graduated in philosophy, politics and economics at Oxford six years earlier; nothing in Macdougall's background suggests he possessed the kind and degree of specialised expertise these articles exhibit. But not only are the 'Telemachus' briefs in Smith's Weekly clearly Macdougall's work, so too are the two letters to the editor of the Sydney Morning Herald and the first of the long articles published in that newspaper, the personal account of the 'dole experience' quoted above. Bizarrely, the only 'solution' to the puzzle would seem to be that the two men used the same pen-name in the same newspaper, though not at quite the same time; that Fairfax in effect 'took over' the pen-name from Macdougall by explicit agreement (their paths are likely to have crossed in Sydney) in 1931, perhaps for no better reason than that he liked the classical name and felt-as I suggested Macdougall may also have done-an urge to honour his father, who had died three years earlier. ${ }^{52}$ Macdougall was certainly the author of another piece, a long, heavily researched and no doubt well-paid article published under his own name in the Home Annual for 1932 - a comprehensive overview, with photographs, of the state of Australia's primary industries. ${ }^{53}$

At the beginning of 1932, however, opportunity came knocking in the form of an invitation to apply his talents as a publicist and fundraiser to the planned celebrations for the opening of the new Sydney Harbour Bridge. Though not the chief organiser of the event, he was tasked with publicising it effectively, and was widely credited with giving it not just a local, but also a national and even international dimension.

\footnotetext{
50 'Man Who Told World About Bridge'.

51 Gavin Souter, Company of Heralds: A Century and a Half of Australian Publishing, 1831-1981 (Melbourne: Melbourne University Press, 1981), 180.

52 Bridget Griffen-Foley, 'Fairfax, Sir Warwick Oswald (1901-1987)', Australian Dictionary of Biography. Volume 17 (Canberra: National Centre of Biography, The Australian National University, 2007), adb.anu.edu.au/biography/ fairfax-sir-warwick-oswald-12475/text22439.

53 D.G. Macdougall, 'Australia's Great Primary Industries', The Home Annual: Australian Life and Scenery, [Sydney], 1 October 1932, 25-42.
} 
The Smith's Weekly reporter, writing two weeks after the grand opening, thought Macdougall had the Midas touch when it came to public relations, and added, with a glance at the bush poets:

Lest it be asked who is Macdougall, it may be stated that as an organiser, when the raising of funds is in the air, he is the Macdougall who has topped Australia's score more than once. He was official publicity man for the Bridge, sent all the dope, abroad that was printed in British and foreign papers, and turned quite a lot of news loose on the Sydney and particularly the country Press, which was regularly fed from that source. ${ }^{54}$

The success of the event, it was said, owed much to the creation of the Citizens' Harbour Bridge Celebrations Committee, of which Macdougall was both publicity officer and organising secretary-responsibilities he retained when the committee was continued on an ongoing basis as the Citizens of Sydney Organising Committee under the chairmanship of Sir Samuel Hordern in 1932. It was an inclusive and highly proactive body, claiming to represent 'every section in New South Wales' and promoting a wide range of community initiatives; some, like the Oberammagau Passion Play performance in April 1933, it supported indirectly (and defended vigorously); with others, it was directly involved in publicity, fundraising and organisation. These included the Sydney Festival, inaugurated as an annual week-long program of celebrations before the Easter Show in 1933, the City of Sydney Eisteddfod, the Sydney Garden Month and the Sydney Gala Week. The eisteddfod was given a Hollywood twist in its second year (1934) when the 'syllabus' included a nationwide 'screen personality test', with the winning finalists (adults and juveniles) to receive free tuition from the Cinema Academy and a screen test with Cinesound, 'with the possibility of a role'. ${ }^{55}$

By 1934, in fact, the Sydney Festival Week had grown to a Festival Fortnight, even boasting a royal visitor, Prince George, the second youngest son of King George V. Macdougall wrote an informative and not overly obsequious article for The Home with advice on the etiquette of royal encounters. ${ }^{56}$ (In the event, with just a few weeks' notice, and for reasons unspecified, Prince George was replaced with his older brother Prince Henry, Duke of Gloucester, whose reward was to become Australia's eleventh Governor-General in 1945.) Macdougall was spoken of in the Sydney press at this time as 'a big man for a big job':

He towers above the average citizen in height, and he would make the ordinary weighing scale spring to attention. Yet he is a mild-mannered fellow with a good share of shrewdness and tact. ${ }^{57}$

54 Smith's Weekly, Saturday, 2 April 1932, 4.

55 'Sydney Eisteddfod: Screen Test, Country Arrangements', Evening News, [Rockhampton, Qld], Friday, 1 June $1934,8$.

56 D.G. Macdougall, 'Meet the Prince', The Home: An Australian Quarterly 15, No. 3 (1 March 1934): $45,83$.

57 'His Big Job', Daily Telegraph, [Sydney], Saturday, 20 January 1934, 6. 
Such was the respect for Macdougall and the Sydney committee that their Melbourne counterparts sought their advice and cooperation in designing that city's centenary celebrations for $1934 .{ }^{58}$ In the year following, 1935, Macdougall was instrumental in organising and publicising the NSW celebrations of the silver jubilee of King George V, for which, as secretary of the Citizens' Committee, he received the King's Medal. ${ }^{59}$

There was still one more major project to come in Macdougall's remarkably long and active career-probably his biggest organisational challenge yet: the Australian sesquicentennial celebrations of 1938, for which he was, from the start of planning, the general organising secretary. Lobbying and preparations for this ambitious, and by no means uncontroversial, commemoration started in early $1936 .{ }^{60}$ National and international publicity was intensive and comprehensive, as Macdougall himself explained in an article published in Brisbane's Courier-Mail just two weeks after the end of the celebrations, as a guide and stimulus to those planning a 1940 celebration for the centenary of European settlement in Queensland:

Publicity took many forms apart from the Press. Hundreds of window displays were arranged, and more than 2000 broadcasts, featuring the celebrations, were given outside Australia. The interest of shipping offices and travel agencies was stimulated, and literature and posters were issued through them. An organised force of 1400 amateur radio operators gave nightly broadcasts throughout the world on the subject of the celebrations. ${ }^{61}$

It all came together famously (perhaps also notoriously) with the elaborate reenactment, at 8.30 on the morning of Wednesday, 26 January, of Arthur Phillip's landing 150 years before at Farm Cove, followed by a huge pageant, 'Australia's March to Nationhood', the progress of which through the streets of Sydney was watched by an estimated 750,000 people. Numbers were boosted by Macdougall's trademark insistence — a 'synergist' avant la lettre — that as many other organisations and events as possible should coincide with this event: 'International, Empire, and inter-State conferences and congresses brought thousands to the State. ${ }^{62}$ One synergy he may not have foreseen, however, and would probably rather have avoided, was with the Aboriginal Day of Mourning, a national event organised by the Aborigines Progressive Association (APA) and the Australian Aborigines' League (actively supported by, among others, the Congregational Church, the Australian Communist Party and the Rationalist Association), to coincide with the start of

58 'Sydney's Co-operation: A Cordial Understanding', The Age, [Melbourne], Thursday, 16 November 1934, 8.

59 'Death of Citizens' Committee Official', Daily Telegraph, [Sydney], Thursday, 17 July 1947, 6. This was, however, not a particularly exclusive award; he was one of 1,800 recipients in New South Wales!

60 'Commemorative Stamp: 150th Anniversary of New South Wales', The Age, [Melbourne], Saturday, 28 April 1936, 22.

61 D.G. Macdougall, 'Sesquicentenary Organisation is Model for Queensland', Courier-Mail, [Brisbane], Wednesday, 11 May 1938, 6.

62 Macdougall, 'Sesquicentenary Organisation is Model for Queensland'. 
the official sesquicentennial program. The protest was covered, briefly but not unsympathetically, by the mainstream Sydney papers; even the Sydney Morning Herald was prepared to quote from the speech of Jack Patten, president of the APA:

We, as aborigines, have no reason to rejoice on Australia's 150th birthday ... This land belonged to our forefathers 150 years ago, but to-day we are being pushed further into the background. Aborigines throughout Australia are literally being starved to death. ${ }^{63}$

Sydney's Daily Telegraph also reported on the coercive recruitment of and poor accommodation provided for the Aboriginal men from the Menindee Mission in the state's far west who had been brought to Sydney to take part in the potentially humiliating portrayal of retreat and flight from Phillip's landing party. ${ }^{64}$ Some of the provincial papers published even longer and more sympathetic articles, ${ }^{65}$ and the Workers' Weekly in Sydney launched a full-scale defence of the protest and its justification, together with a withering critique of past and present treatment of the Aborigines and of the celebratory themes of the sesquicentenary as a whole:

History is to be completely falsified-not merely by means of the omissions but even in the episodes and items selected to be dealt with. Captains of industry and trade lose all their sordidness and taint of greed when seen through official spectacles, nor are we presented with comparative pictures showing how a vile commercialism has destroyed the beauties of our forests, the foreshores of innumerable bays of our harbors and the souls of our children born and bred in the slums that have replaced the virgin bush that Phillip gazed upon. ${ }^{66}$

The sesquicentenary was 'one big orgy of profit-making' in which floats, favours and privileged access were sold: 'Capitalist initiative and enterprise have full play.' (To the last charge, at least, Dugald Macdougall would probably have responded: 'And your point is?'.)

If Macdougall did respond to some of the broader and more trenchant attacks on the 'sesqui', he seems not to have done so in the popular press. He did, however, notice and respond to the charge from the other end of the political spectrum that it gave too little attention to Australia's military achievements - a choice for which he accepted full responsibility, and which he defended tactfully but firmly

63 'Aborigines. Day of Mourning. Emphatic Protest', Sydney Morning Herald, Thursday, 17 January 1938, 6.

64 'Natives Here for Mourning Congress. Anniversary Day Protest', Daily Telegraph, [Sydney], Monday, 24 January $1938,2$.

65 See, for example, 'Aborigines. "Day of Mourning”. Conference in Sydney', Daily Examiner, [Grafton, NSW], Thursday, 27 January 1938, 5; 'Current Comment. Aborigines' Day of Mourning', Cootamundra Herald, Friday, 4 February 1938, 6 [reprinted from the Wagga Daily Advertiser].

66 'Australia's Real Tradition. The Struggle for Freedom and a Better Life. Ignored by Official Celebration', Workers' Weekly, [Sydney], Monday, 24 January 1938, 1. For a fuller account of the celebrations and their critique, see Aimee Volkofsky, "We Thought They Were Going to be Massacred": 80 Years Since Forced First Fleet Re-Enactment', ABC Broken Hill, 25 January 2018, www.abc.net.au/news/2018-01-25/eighty-years-since-forced-first-fleetreenactment/9358854. 
in the press. ${ }^{67}$ And he continued to advocate for more and bigger memorial celebrations - 'firstly, from a sense of national pride and achievement felt by people with so young a historical background; secondly, the urge to follow other nations and "Tell the World"'.68

It must have seemed, nonetheless, a slightly sour note on which to end a prominent and successful public career. But, as a whole, that career was characterised by the same irrepressible energy, optimism, determination and public spirit that were praised in the testimonials to and obituaries for his father, and on his own death in 1947. In addition to these fairly generic attributes of the successful colonial entrepreneur, there was also an unusually strong sense of identification in both men with the particular town-Bendigo in the one case, Sydney in the other-to which they devoted most of their developmental, communicative and commemorative energies. If similarities there were, they can probably be assigned to nature rather than nurture, since Dugald senior died when his son was seven years old. And yet, despite leaving Bendigo for Dalby just three years later, the son had fond memories of the place - and perhaps also of the man - and regretted being unable to attend the first 'Back to Bendigo' week in 1917. In a letter to the secretary of the Easter Fair, duly reported in the Bendigo Advertiser, he noted his father's terms as mayor and town clerk in the 1870 s. ${ }^{69}$ Many years later, in the early Depression years, he drew on his father's pioneering work in the goldmining industry in Bendigo to support a scheme for putting the unemployed to work as gold prospectors. ${ }^{70}$

In other words, notwithstanding the apparently wide geographical and chronological discontinuities between the lives of father and son, an explicit connection seems to have been made, and remade, by the latter throughout his adult life, such that whatever its psychological or emotional underpinnings—and one can only speculate about these-it came to constitute a publicly acknowledged bridge across the two (male) generations, enabling the reproduction (in effect, the bequeathing) of certain public dispositions and preoccupations from father to son: a driving work ethic, a devotion to public service, a strong attachment to particular human communities, a belief in the virtues of liberal democracy and capitalist free enterprise, a respect for wealth, some sympathy (real but limited) for the plight of the less fortunate and an irrepressible optimism about the future of the Australian colonies and the new nation within the British Empire.

67 'Acts of Peace, Not War: Pageant Arrangements', The Argus, [Melbourne], Thursday, 27 January 1938, 2.

68 Macdougall, 'Sesquicentenary Organisation is Model for Queensland'.

69 'Former Mayor and Town Clerk', Bendigo Advertiser, Wednesday, 11 April 1917, 6.

70 D.G. Macdougall, 'Search for Gold. To the Editor of the Herald', Sydney Morning Herald, Thursday, 22 January 1931, 4 . 


\section{James Claude Macdougall (1903-1995) ${ }^{71}$}

Unlike his father, whose adult career began several years after his own father's death in 1879, Jim Macdougall enjoyed a 44-year overlap with the younger Dugald, including many years living in the same cities (Melbourne, then Sydney) as adults and working in more or less the same profession of journalism. Jim was not the only member of the family to enter his father's primary profession (his older brothers, Carlyle and D'Arcy, were also journalists), but he was the best-known of the three, and his father's influence in the early part of his career was unusually direct and explicit.

After the family moved to Melbourne, Jim attended Wesley College (1917-19) ${ }^{72}$ and then spent some happy years jackarooing on a pastoral property in the southern Riverina owned by Sir George Fairbairn, a friend of his father. ${ }^{73}$ Here his life took a decisive turn in 1923 when his father showed another prominent acquaintance, (Sir) Keith Murdoch, a poem Jim had composed while droving sheep, on the strength of which-according to Jim-Murdoch hired him as a cadet reporter on the Melbourne Herald. ${ }^{74}$ Jim started the job in 1924 and, after a year-impressed by his eye for a good story-Murdoch sent him to Fleet Street to 'learn the trade' for two years at the Herald's London bureau. ${ }^{75}$ Jim returned to Melbourne at the end of 1926 to be met by a 'request' from Murdoch that he move in with the poet C.J. Dennis, then a columnist on the Herald staff, in an effort to moderate the latter's heavy drinking. Macdougall ended up sharing 'Den's' Collins Street flat for several months. ${ }^{76}$ Later that year, he made Australian radio broadcasting history when, on 25 August 1927, he conducted an interview from Melbourne with a subject in Sydney that was transmitted live in both cities.

In August 1932, after a six-week courtship, ${ }^{77}$ he married Olive McKnight, daughter of a prominent surgeon in Albury, NSW. ${ }^{78}$ Soon afterwards, he resigned from the Herald and the newlyweds sailed for Europe. Basing themselves in Surrey, they visited several European countries and returned to London for the birth of their son Mikael in March 1934, an event Jim proudly proclaimed, by cable and

\footnotetext{
71 This section expands my $A D B$ article on Jim Macdougall: Patrick Buckridge, 'Macdougall, James Claude (Jim) (1903-1995)', Australian Dictionary of Biography (Canberra: National Centre of Biography, The Australian National University, 2019), adb.anu.edu.au/biography/macdougall-james-claude-jim-22810/text32272.

72 Wesley College Chronicle, [Melbourne], August 1917, No. 150, 4; May 1920, No. 158, 16. (Available online from Wesley College Archives.)

73 'Jim Macdougall Interviewed by Stewart Harris', [Sound recording], NLA Oral History and Folklore Collection, 10 November 1993, National Library of Australia, Canberra; Helen Verlander, 'Columnist's Flights of Fancy Really Took Off, The Australian, 15 August 1990, 4; 'Obituary', The Australian, 14 September 1995.

74 'Jim Macdougall Interviewed by Stewart Harris'; 'Obituary'.

75 'Obituary'; Jim Macdougall, 'In the City of Doreens', Quadrant (November 1976): 60.

76 Macdougall, 'In the City of Doreens'.

77 Verlander, 'Columnist's Flights of Fancy Really Took Off.

78 'Intimate Jottings', Australian Women's Weekly, Saturday, 31 March 1934, 31.
} 
letter, to the Australian Women's Weekly. ${ }^{79}$ Soon afterwards, Jim was cycling across Nazi Germany with Ronald Hughes-Jones, ${ }^{80}$ a journalist friend from Melbourne. In Vienna, he interviewed the Austrian chancellor Engelbert Dollfuss, two months before his assassination, met the famous actor Emil Jannings and conversed with the composer Franz Lehár. 'A wonderful business man', Jim said of Lehár with characteristic admiration:

He kept a book showing exactly how many times his compositions had been played in the important cities of the world, and was able to tell at a glance whether 'The Merry Widow' was more popular in Adelaide than Melbourne or Sydney. ${ }^{81}$

He then travelled alone to the Balkans, where he worked briefly on the South Slav Herald $^{82}$ (an English-language newspaper published in Belgrade), pursued a story about tsarist treasure in Dubrovnik (which he sent to the Newcastle Sun), ${ }^{83}$ visited monasteries in Macedonia, met Prince Nicholas of Greece painting landscapes by a roadside in the Julian Alps and languished in prison for two days in Skopje for a passport violation. ${ }^{84}$

Crossing the Mediterranean, he joined the Remo at Port Said, ${ }^{85}$ having visited some 17 countries, ${ }^{86}$ and arrived back in Australia in September to be reunited with Olive and Mikael, who had arrived from England a month earlier ${ }^{87}$ with a breeding pair of dalmatians and a cocker spaniel. ${ }^{88}$ They were joined a few months later by what was said to be the first Afghan hound ever imported into Australia. ${ }^{89}$ Perhaps with assistance from Olive's father, Jim and Olive established dog studs in Sydney and Melbourne, ${ }^{90}$ breeding, exhibiting and selling pedigreed dogs—an enthusiasm they shared for the rest of their lives. ${ }^{91}$

A few months after his homecoming, Jim reunited with his recent travelling companion for a very different sort of adventure. In August 1935, he and Hughes-Jones drove a heavy truck 2,800 kilometres from Melbourne to Tennant Creek in the Northern Territory carrying a 3,900-litre tank of water, to be left there for the use of its mining population of 600 people. Is it fanciful to find a cross-generational interest in the water supply to Australian rural communities?

\footnotetext{
79 'Intimate Jottings'.

80 'Journalists to Cart Water in Interior', The News, [Adelaide], Friday, 23 August 1935, 3.

81 'Melbourne Journalist: Experiences in Europe', Sydney Morning Herald, Saturday, 22 September 1934, 23.

82 Verlander, 'Columnist's Flights of Fancy Really Took Off.

83 James Macdougall, 'Hidden Hoards: Exiled Czarists on Treasure Search', Newcastle Sun, Thursday, 3 January 1935, 12.

84 'Journalists to Cart Water in Interior'.

85 Passenger Arrival Index, National Archives of Australia, Canberra.

86 'Journalists to Cart Water in Interior'.

87 Passenger Arrival Index.

88 'Items of Interest,' The Argus, [Melbourne], Friday, 24 August 1934, 5.

89 'Afghan Hound', Sydney Morning Herald, 12 April 1935, 12.

90 Inference from advertisement in Table Talk, [Melbourne], Thursday, 19 September 1935, 46.

91 Jim Oram, 'Farewell, Jim!', Daily Mirror, [Sydney], Monday, 23 December 1974, 2.
} 
Jim's grandfather had, after all, designed the Crusoe Reservoir in Bendigo, and his father was an enthusiastic advocate for the sinking of artesian bores in the outback (he wrote a long article for The Sydney Mail on the subject the year after his son's Aquarian expedition). ${ }^{92}$

Jim's first job back in Australia was as a subeditor and occasional feature writer for The Star in Melbourne and then, from 1937, as subeditor, then pictorial editor, of Sydney's Daily Telegraph. ${ }^{93}$ In 1941, having been rejected for military service because of a bleeding ulcer, ${ }^{94}$ he moved to the Sydney Sun, where, five years later, the defining opportunity of his life arrived. His daily column, 'Contact', first appeared on 18 February 1946, a week or so later than David McNicoll's 'Town Talk' in the Daily Telegraph. ${ }^{95}$ Together with Sydney Deamer's 'Column 8', which began in the Sydney Morning Herald 11 months later, these were the first American-style front-page columns in Australian newspapers. 'Contact' was the perfect expression of Macdougall's personality, surmounted by his signature and reflecting (as his then rival McNicoll graciously acknowledged) his 'sunny and gregarious disposition'. ${ }^{96}$ Widely plundered for individual items by provincial and interstate columnists, the 'Contact' column was typically a series of half a dozen or more paragraphs of society gossip, business and political news, humorous or appealing stories and whimsical one-liners.

It is difficult to exemplify the particular quality of Jim's columns-benevolent whimsy, guileless quirkiness, mischievous mockery?-by selective quotation. As a humorous columnist, he was no Lennie Lower or Ross Campbell (let alone an Art Buchwald, the legendary Washington Post columnist he sometimes quoted). ${ }^{97}$ Indeed, it is probably true to say that, then as now, many of Jim's jokes, qua jokes, would be more likely to elicit groans than belly laughs, which he sometimes acknowledged:

DISGUSTING: 'You're the Fifth Columnist I've met this week,' a friend told me. ${ }^{98}$

I'm taking a Gallup poll next week to see who's had the roughest Trot. ${ }^{99}$

TOMORROW: I am launching my Food for Thought Fund. My shoeshine has already given me a piece of his mind. ${ }^{100}$

92 D.G. Macdougall, 'Our Liquid Wealth', The Sydney Mail, Wednesday, 22 July 1936, 41-42.

93 Newspaper News, 1 September 1939, 17.

94 Verlander, 'Columnist's Flights of Fancy Really Took Off'.

95 David McNicoll, Luck's a Fortune: An Autobiography (Melbourne: Sun Books, 1979), 116.

96 McNicoll, Luck's a Fortune, 119.

97 'Contact', Daily Telegraph, [Sydney], 10 February 1956.

98 'Contact', The Sun, [Sydney], Wednesday, 20 February 1946, 1.

99 'Contact', The Sun, [Sydney], Thursday, 21 February 1946, 1.

100 'Contact', The Sun, [Sydney], Tuesday, 19 February 1946, 1. 
Often he credited the witticisms to others: 'As Joe, the fellow who sells papers round the mid-town banking area says, you're not supposed to repeat gossip, but what else can you do with it? ${ }^{101}$

Sometimes the tone is not so much humorous as wistful:

I met a fellow in the street the other day I used to go to school with. It was a very sad meeting. You see, he's grown up since then, and I haven't. ${ }^{102}$

And sometimes—not often-the humour is mildly risqué in a mid-century style that has not travelled well: 'An amusement park at Manly has penny-in-the-slot machines showing "beautiful Australian girls" -in the nude. I could hardly believe my eyes. I had to have another look. ${ }^{303}$

Occasionally he draws upon the wisdom of his father, with whom, clearly, he had a warm relationship:

You can't wander through life without picking up a peg or two to hang your philosophy on. I can remember my father's massive hand enfolding mine. I was snivelling about life. All he said was, 'Remember Jimmie, two men once looked through prison bars; one saw mud - the other STARS. ${ }^{104}$

But more often he defers to his dog-a dynasty of dalmations—which (or whom?) he credits for his lamer witticisms: 'That big dog of mine says you can only describe a Dachshund as a long-short dog. That dog's a fool. ${ }^{105}$

But his staple source and subject was not himself or his family but, as he put it, 'the brain, the wit and the wisdom of the people of Sydney', ${ }^{106}$ from whom, at the peak of his career, he was receiving nearly a thousand letters and phone calls every week. ${ }^{107}$ In return, he often used his column to highlight individual cases of hardship or injustice and to lend his support to deserving charities. Sometimes a charitable impulse could go off half-cocked. In 1947, he discovered that Jack Moses, the bush bard who wrote 'Nine Miles from Gundagai', was buried in South Head Cemetery with no inscription on his headstone.

101 'Contact', Daily Telegraph, [Sydney], 31 January 1956, 2.

102 'Contact', The Sun, [Sydney], Friday, 22 February 1946, 1.

103 'Contact', The Sun, [Sydney], Tuesday, 19 February 1946, 1.

104 'Contact', Daily Telegraph, [Sydney], 10 February 1956, 2.

105 'Contact', The Sun, [Sydney], Monday, 11 March 1946, 1.

106 Verlander, 'Columnist's Flights of Fancy Really Took Off.

107 Supplement [Daily Mirror Silver Anniversary feature], Newspaper News, 29 April 1966, 11. 
[T]he Sydney 'Sun' columnist Jim Macdougall called attention to this and appealed to Jack's old mates to contribute the cost of a suitable inscription. Money rolled in from all quarters. But then Macdougall learned that it was Jack's own wish that the headstone should make no reference to him at all—not even his name; so Macdougall is returning all the money sent in to him. ${ }^{108}$

Following the acquisition of Associated Newspapers (publishers of the Sun) by the Fairfax Group in 1956, Macdougall resisted pressure from Lindsay Clinch, the new editor of the (now) Sun-Herald, to 'start kicking people in the guts' in his column. ${ }^{109}$ As a consequence, he migrated, with 'Contact', to Frank Packer's Daily Telegraph, a transition signified by the first appearance of his distinctively puckish caricature with big spectacles, long nose, abundant black hair and stylish buttonhole. Resentment at his and others' recent rough treatment by Fairfax management made him agree to write two paragraphs sharply critical of their corporate behaviour and journalistic standards. He then had to defend his own integrity in the public hostilities that ensued. ${ }^{110} \mathrm{He}$ later reflected ruefully on the experience in his column:

Good morning: Take it from one who has been through the college: resentment is one of the killers of human happiness. It walks with you and sleeps with you. And you get nothing from it. ${ }^{11}$

For the next five years, he retreated to his column, now located on the back page of the Daily Telegraph. The jokes were as endearingly lame as ever, his relationship with his readers even more relaxed, affectionate and personal, and the anecdotes a little longer. Then, at the height of his popularity, he accepted an offer from the Sydney Daily Mirror, where his column continued to provide 'the light-hearted lowdown on life', now seven days a week (Sunday Mirror included), ${ }^{112}$ with a new title, 'Town Talk', and a photographic headshot. A new strain of Sydney nostalgia began to appear: several items begin with 'Things I like about Sydney' and proceed to describe an old saloon bar, a laconic bus driver, a Sunday excursion or something else redolent of the city's more understated charms:

Are you, too, fond of the vanishing old world charm of Sydney? (Speak up, sir; I can't hear you!) Well, take a stroll some warm and balmy Sunday, like yesterday frinstance, up to the little park that sits between the frowning walls of the Old Gaol and St. Vincent's Hospital. ${ }^{113}$

108 'Over the Sliprail', The Worker, [Brisbane], Monday, 17 November 1947, 4.

109 McNicoll, Luck's a Fortune, 249-56; Bridget Griffen-Foley, The House of Packer: The Making of a Media Empire (Sydney: Allen \& Unwin, 2000), 226-27.

110 McNicoll, Luck's a Fortune, 254.

111 'Contact', Daily Telegraph, [Sydney], 7 February 1956.

112 'Jim Macdougall Has Never Been Happier', Cumberland Argus, [Sydney], 18 January 1961, 14.

113 Jim Macdougall, 'Town Talk', Daily Mirror, [Sydney], Monday, 23 January 1961. 
He called 'Town Talk', which ran for 14 years, his 'corner of warmth in the paper', and his readers agreed. ${ }^{114}$ As a 'Mirrorman', Macdougall established his reputation as 'perhaps Australia's best-known columnist', ${ }^{115}$ with an uncanny knack-still credited to either his 'crystal ball' or 'the spotted dog'-for accurately predicting honours awards, senior political appointments and Archibald Prize winners. ${ }^{116}$ The truth was, of course, he had an enormous network of obliging informants all over Sydney, and most of them were happy to leak. As he himself once observed, with his usual self-mockery: 'Don't I have a lot of friends?' ${ }^{117} \mathrm{He}$ was honoured with an Order of the British Empire in 1969 and a Commander of the Order of the British Empire five years later for services to journalism — and no doubt knew about them well in advance. ${ }^{118}$

Though he officially retired at the end of $1974,{ }^{119}$ Macdougall took a job with Cathay Pacific Airways the following year to write a regular weekly column in The Australian, 'Jim Macdougall's Cathay Commercial', which ran until his 'real' retirement in 1991. During these years, he also contributed a weekly column to his local newspaper, the North Shore Times. ${ }^{120} \mathrm{He}$ died of a heart attack at his home in Lindfield, Sydney, ${ }^{121}$ survived by his wife and son, and was cremated at the Northern Suburbs Crematorium.

\section{Conclusions}

The quasi-dynastic sequence of the three Macdougalls might be read simply as a three-stage tradition (in the classic Shilsian sense) of journalism-in-the-family. All three men were journalists, the first by repute (I have been unable to verify his authorship of specific articles in the local press, but he is said to have written several), and the second and third Macdougalls were both journalists in a fully professional sense, but also in very different ways and different spheres. There is even, as was noted, a significant similarity between the anecdotal humour and gossip of some of Dugald junior's pieces for Smith's Weekly and those of his son's columns. Nonetheless, this seems at best an incomplete reading of the series formed by their lives and careers.

114 Matt White, 'The Daddy of Sydney Columnists', Daily Telegraph-Mirror, [Sydney], 5 September 1995, 62.

115 Newspaper News, 29 April 1966.

116 'Obituary', The Australian, 14 September 1995; 'Columnist Inspired by the Man in the Street', Sydney Morning

Herald, 5 September 1995, 4.

117 'Contact', The Sun, [Sydney], Friday, 29 March 1946, 1.

118 It's An Honour website (Canberra: Department of the Prime Minister and Cabinet, n.d.), www.pmc.gov.au/ government/its-honour.

119 Oram, 'Farewell Jim!'.

120 'Noted Scribe Dies at 92', North Shore Times, [Sydney], 8 September 1995, 6.

121 White, 'The Daddy of Sydney Columnists'. 
A second, complementary possibility is to read the Macdougall series as an ideological continuum across the generations. The vigorously pro-capitalist, pro-business, pro-development, free-enterprise attitudes of the first Dugald were tempered by his strong support for, and involvement in, community-building organisations and activities, ethically responsible administration of public institutions and facilities and the implementation of liberal reformist principles and policies in local and colonial government. The second Dugald, though only seven years old when his father died, nonetheless embraced substantially that same mix of values and attitudes (with explicit deference to his father and Bendigo), expressing them in his own administrative work but also, more discursively, by advocacy and dissemination through his work as a newspaper editor and publicist. Since his father's day, the Australian political landscape had changed a lot, with Federation and the emergence of the Australian Labor Party; and that mix of pro-business attitudes, nationalism, monarchism and 'small-l' liberal values tended to align him consistently with the non-Labor side of politics. Jim Macdougall similarly, though perhaps more reticent than either of his predecessors about his political allegiances, says enough to indicate a leaning towards the right of the political spectrum, and he mixed socially, as his father had always done, with the business and bureaucratic elites at the 'top end of town', articulating many of their values and assumptions in his columns. But he was also adept — as his particular kind of journalism demanded—at sharing and giving voice to the pleasures, anxieties and irritations of ordinary Sydneysiders of every class and occupation, who liked him and whose company he clearly enjoyed.

It is also necessary to acknowledge, with regret, that all three Macdougalls evinced, at times, a less than sympathetic understanding of the experience of Aboriginal Australians: the elder Dugald in an unfortunate description of the district around Bendigo before his time as 'an untenanted waste, having only for its denizens the benighted aboriginals and the wild beasts'; ${ }^{122}$ the younger in his apparent complicity with the poor treatment of the Aboriginal participants in the sesquicentenary reenactment; and Jim in his one-sided treatment of the Coniston massacre in a feature article for the Melbourne Star in $1936 .{ }^{123}$ Of this unhappy continuity, I would say only that while history can never fully excuse such attitudes-strongly critical viewpoints were voiced contemporaneously, at least on the last two eventsthe Macdougalls' views were in the mainstream for their times.

While the ideological model provides some purchase on substantive continuities within the series, it somehow fails to capture its internal dynamic and indeed its vitality. This is because reducing the three men to their ideas and attitudes tends to exclude their differences from one another, and also their interplay as individuals. More complex and nuanced versions of this model have been applied to collective

122 'Memorial Stone of the Bendigo Bells'.

123 James Macdougall, 'They Died Back o' Beyond', Glen Innes Examiner, Thursday, 27 February 1936, 3 [reprinted from Melbourne Star]. 
biographies of a very different sort. For example, in the ongoing debate about the kind and degree of unity to be found among the Inklings, that group of Oxford writers and scholars surrounding C.S. Lewis and J.R.R. Tolkien in the middle of the twentieth century, a conception of 'world view' (Weltanschauung) has recently been invoked, in its Freudian version, as

an intellectual construction which solves all the problems of our existence uniformly on the basis of one over-riding hypothesis, which, accordingly, leaves no question unanswered and in which everything that interests us finds its fixed place. ${ }^{124}$

Such a concept provides greater scope than 'ideology' or 'tradition' for accommodating the diversity and mutual interactivity of the Macdougalls' careers, but fails to give sufficient weight to the fact that they belonged to different generations (and therefore, to some extent, different 'worlds') and that they were, self-consciously, members of the same family. Furthermore, while all three were highly intelligent, articulate and well-read, none of them was an 'intellectual' (in the usual, restricted sense in which the Inklings clearly were) or would have wanted to be regarded as one. Something different from 'world view', then, may be needed to illuminate such qualities as the commercialism, curiosity, sociability, patriotism, humour, civility and decency that seem to inform the social and professional behaviour of all three Macdougalls in varying admixtures, while at the same time highlighting their differences and complementarities as social actors.

Perhaps that purpose may be served by a simple notion of 'praxis', here used in one of its most basic meanings, as 'the act of engaging, applying, exercising, realizing, or practising ideas' in society. ${ }^{125}$ It can allow broad but valid differentiations to be made as to the kinds of social action and the specific forms of praxis that characterised the three men's careers.

The first, that of Dugald senior, we might regard as a praxis of building, inasmuch as he spent his career developing an industry, civic institutions and physical facilities that embodied his ideas about civil society. The second, that of Dugald junior, we might regard as preeminently a praxis of publicity, inasmuch as his career-as journalist, publicist, promoter and organiser-was largely devoted to publicising and celebrating precisely the sorts of industries, institutions and material fabric that his father's generation had built in Australia, though it also involved, on his part, the construction of administrative systems and communication networks of his own.

124 Quoted by Zachary A. Rhone, The Great Tower of Elfland: The Mythopoeic Worldview of J.R.R. Tolkien, C.S. Lewis, G.K. Chesterton and George MacDonald (Kent, OH: Kent State University Press, 2017), 6-7. Rhone uses the concept to challenge Humphrey Carpenter's (1978) influential revisionist view that the differences between the various members' writings and attitudes were greater and more important than their similarities.

125 'Praxis (process): Marxism' (Wikipedia, 2019), en.wikipedia.org/wiki/Praxis_(process)\#Marxism. 
The third, that of his son Jim, I want to describe as a praxis of participation. This also involved celebration-in a more personal and less promotional mode than his father's-as well as a lot of additional social network-building. It involved other activities, too, as components of the larger praxis, but above all Jim's career as a journalist (and, unlike his father and grandfather, he was never really anything else) was permeated by what might be called an 'existential' praxis, that of simply being an ordinary, but mindful and communicative participant in the day-today life of the city of Sydney. The trivia, the gossip, the lame jokes, the passing encounters, the fond memories, the sentimental moments, the moments (very rare) of irritation or melancholy, the feelings of sympathy, admiration and support, the recommendations of some worthwhile or pleasurable Sydney experience-all these and more are part of what 'living in Sydney' felt like to Jim Macdougall, and he wanted to share it with others, if only for a few minutes a day.

What is noteworthy about this sequence of three careers, as just describeddistilling them into three different forms of praxis does serve to highlight this fact about them-is that, within their ideological similarities, they are not only different one from the other, but also progressively enabling. That is, the nature of Dugald junior's career was at least in part an ongoing work performed upon the career of his long-deceased father, and similarly, the distinctive character and function of Jim's columns - for all their relaxed naturalness - were an ongoing work performed on the legacy of his father and, less directly, his grandfather. Each of the three careers is thus modified by its relation to the others, and the last two might even be seen as realising some of the unrealised possibilities inherent in the careers of their respective predecessors. For these reasons, there is indeed something about the Macdougalls' combined historical significance that exceeds the sum of their three careers: together they constitute a 'Macdougall mini-dynasty', in effect, which enacted a certain set of liberal ideas and values regarding economic development, social progress, ethical integrity, national and civic pride, community, civility and human happiness across three generations and 120 years of Australia's history. 
This text is taken from Australian Journal of Biography and History: No. 3, 2020, published 2020 by ANU Press, The Australian National University, Canberra, Australia.

doi.org/10.22459/AJBH.2020.03 